\title{
Distinct patterns of APP processing in the CNS in autosomal-dominant and sporadic Alzheimer disease
}

\author{
Marta Pera $\cdot$ Daniel Alcolea $\cdot$ Raquel Sánchez-Valle $\cdot$ Cristina Guardia-Laguarta $\cdot$ Martí Colom-Cadena $\cdot$ \\ Nahuai Badiola $\cdot$ Marc Suárez-Calvet · Albert Lladó • Alvaro A. Barrera-Ocampo • Diego Sepulveda-Falla • \\ Rafael Blesa · José L. Molinuevo · Jordi Clarimón · Isidre Ferrer · Ellen Gelpi · Alberto Lleó
}

Received: 22 May 2012/Revised: 10 October 2012/Accepted: 27 October 2012/Published online: 6 December 2012

(C) The Author(s) 2012. This article is published with open access at Springerlink.com

\begin{abstract}
Autosomal-dominant Alzheimer disease (ADAD) is a genetic disorder caused by mutations in Amyloid Precursor Protein $(A P P)$ or Presenilin (PSEN) genes. Studies from families with ADAD have been critical to support the amyloid cascade hypothesis of Alzheimer disease (AD), the basis for the current development of amyloid-based disease-modifying therapies in sporadic $\mathrm{AD}$ (SAD). However, whether the pathological changes in APP processing in the CNS in ADAD are similar to those observed in SAD remains unclear. In this study, we measured $\beta$-site APP-cleaving enzyme (BACE) protein levels and activity, APP and APP C-terminal fragments in brain samples from subjects with ADAD carrying APP or PSEN1 mutations $(n=18)$, patients with $\operatorname{SAD}(n=27)$ and agematched controls $(n=22)$. We also measured $\operatorname{sAPP} \beta$ and BACE protein levels, as well as BACE activity, in CSF
\end{abstract}

Electronic supplementary material The online version of this article (doi:10.1007/s00401-012-1062-9) contains supplementary material, which is available to authorized users.

M. Pera · D. Alcolea · C. Guardia-Laguarta .

M. Colom-Cadena · N. Badiola · M. Suárez-Calvet · R. Blesa ·

J. Clarimón · A. Lleó ( $\square)$

Department of Neurology, Inst. Investigacions Biomediques,

Hospital de Sant Pau, Universitat Autònoma de Barcelona,

Sant Antoni $\mathrm{M}^{\mathrm{a}}$ Claret, 167, 08025 Barcelona, Spain

e-mail: alleo@santpau.es

M. Pera · D. Alcolea - C. Guardia-Laguarta .

M. Colom-Cadena - N. Badiola · M. Suárez-Calvet · R. Blesa ·

J. Clarimón · I. Ferrer · A. Lleó

Centro de Investigación Biomédica en Red en enfermedades

Neurodegenerativas, CIBERNED, Madrid, Spain

R. Sánchez-Valle · A. Lladó · J. L. Molinuevo

Alzheimer's Disease and other Cognitive Disorders Unit,

Department of Neurology, Hospital Clínic, Barcelona, Spain from individuals carrying PSEN1 mutations (10 mutation carriers and 7 non-carrier controls), patients with SAD $(n=32)$ and age-matched controls $(n=11)$. We found that in the brain, the pattern in ADAD was characterized by an increase in APP $\beta$-C-terminal fragment ( $\beta$-CTF) levels despite no changes in BACE protein levels or activity. In contrast, the pattern in SAD in the brain was mainly characterized by an increase in BACE levels and activity, with less APP $\beta$-CTF accumulation than ADAD. In the $\mathrm{CSF}$, no differences were found between groups in BACE activity or expression or $\operatorname{sAPP} \beta$ levels. Taken together, these data suggest that the physiopathological events underlying the chronic $\mathrm{A} \beta$ production/clearance imbalance in SAD and ADAD are different. These differences should be considered in the design of intervention trials in $\mathrm{AD}$.

Keywords Amyloid precursor protein . Autosomal-dominant Alzheimer disease . $\beta$-Site APP-cleaving enzyme $\cdot$ Presenilin $\cdot \beta$-Amyloid

A. A. Barrera-Ocampo · D. Sepulveda-Falla Institute of Neuropathology, University Medical Center Hamburg-Eppendorf, Hamburg, Germany

A. A. Barrera-Ocampo · D. Sepulveda-Falla Grupo de Neurociencias de Antioquia, Faculty of Medicine, University of Antioquia, Medellín, Colombia

I. Ferrer

Institut de Neuropatología, Servei Anatomia Patológica,

IDIBELL, Hospital Universitari de Bellvitge,

University of Barcelona, Barcelona, Spain

E. Gelpi

Neurological Tissue Bank, Biobanc-Hospital Clínic-IDIBAPS,

Barcelona, Spain 


\section{Introduction}

Autosomal-dominant Alzheimer disease (ADAD) is a genetic disorder that accounts for less than $1 \%$ of all $\mathrm{AD}$ cases [6]. It is genetically heterogeneous and has been associated with mutations in the amyloid precursor protein $(A P P)$ gene or in the two presenilin genes (presenilin-1 and -2 or PSEN1 and PSEN2) [6].

Studies in ADAD have been critical to support the amyloid cascade hypothesis, which states that the sequence of pathogenic events leading to $\mathrm{AD}$ is primarily initiated by accumulation of $\beta$-amyloid (A $\beta$ ) [24]. The knowledge derived from these studies has been instrumental in guiding the development of the amyloid-based disease-modifying drugs currently being tested in sporadic Alzheimer disease (SAD).

$\mathrm{A} \beta$ peptide is the major protein component of amyloid plaques observed in the brain of patients with ADAD and SAD and it is produced via sequential cleavage of APP by two proteases, $\beta$ - and $\gamma$-secretases [37]. The prevailing view about the cause of brain $\mathrm{A} \beta$ deposition in ADAD is that APP and PSEN mutations lead to a chronic increase in the absolute or relative production of the fibrillogenic 42-aminoacid-long form of $\mathrm{A} \beta(\mathrm{A} \beta 42)$ that, over time, leads to formation of brain oligomeric $\mathrm{A} \beta$, deposition of fibrillar $\mathrm{A} \beta$ and eventually neurodegeneration [6]. The causes of $\mathrm{A} \beta$ accumulation in SAD are far more complex. A predominant view claims that brain $\mathrm{A} \beta$ deposition in $\mathrm{SAD}$ results from the complex interaction of genetic and environmental factors that end up in a chronic imbalance between $\mathrm{A} \beta$ production and clearance. Different mechanisms have been proposed to explain this chronic imbalance in SAD, such as increased $[19,26,27,34,58]$, altered production [25] or reduced clearance of $\mathrm{A} \beta$ [38]. The investigation to elucidate the molecular mechanisms of $\mathrm{AD}$ has been complicated by the fact that many studies about the pathogenesis of $\mathrm{AD}$ rely on transgenic mouse models that overexpress ADAD-associated mutations. The results of these investigations are often extrapolated to all forms of $\mathrm{AD}$, irrespective of the underlying causes. Elucidating the differences and commonalities between ADAD and SAD in the human CNS is an important topic as the first intervention trials in preclinical and presymptomatic AD are imminent. Although some previous studies have focused on the differences in $\mathrm{A} \beta$ isoforms between ADAD and SAD in the CNS [44-46, 49], other aspects of APP processing remain poorly investigated. In this study, we focused on BACE protein and activity, and their related cleavage products in a large a collection of well-characterized brain and CSF samples from subjects with ADAD carrying APP or PSEN1 mutations, patients with SAD and age-matched controls.

\section{Materials and methods}

Human brain samples

All individuals or relatives had given their written informed consent for research and the study was approved by the local ethical standards committee on human experimentation. Human brain samples were obtained from the Institut de Neuropatologia, Hospital Universitari de Bellvitge, and the Neurological Tissue Bank of the Biobanc-Hospital Clinic-IDIBAPS. We included samples from 10 patients with ADAD (2 with an APP mutation and 8 with PSEN1 mutations, mean age $55 \pm 8.7$ years, Table 1) [2, 23, 35, 36], 19 patients with SAD (mean age $78 \pm 8.0$ years, Braak neurofibrillary stage $=\mathrm{V}-\mathrm{VI}$, Thal phase of $\mathrm{A} \beta=5$ ), and 22 healthy controls (Braak neurofibrillary stage $=0 ; 12$ young controls and 10 elderly controls, mean age $48.7 \pm 13.2$ and $75.1 \pm 6.5$ years, respectively). The mean postmortem interval (PMI) was $7.4 \pm 4.8 \mathrm{~h}$. As a confirmation group we included 8 additional cases with the E280A PSEN1 mutation (mean age $54.5 \pm 4.9$ years) and 8 age-matched cases with SAD from the University of Antioquia Brain Bank (Table 1) [52, 53]. For biochemical analyses we used frozen blocks from the frontal association cortex, known to have high density of amyloid plaques [3, 34]. For immunohistochemical analyses paraffin-embedded samples from several brain regions were used (see below).

\section{Human CSF samples}

A total of $60 \mathrm{CSF}$ samples were included in this study. CSF samples from PSEN1 mutation carriers were part of the Genetic Counseling Program (PICOGEN) [18] at the Hospital Clínic, Barcelona. This group included 10 subjects carrying PSEN1 mutations (5 subjects with ADAD, global deterioration scale $3-5$ and 5 presymptomatic mutation carriers), and 7 non-mutation carriers from the same family (Table 2). The clinical and CSF data of some of these patients have been previously reported [17]. Adjusted age was defined as the subject's age relative to the median age of onset in the family. We also included 32 CSF samples from patients with dementia due to SAD and 11 age-matched healthy controls (mean age $74.6 \pm 5.3$ and $67.6 \pm 4.0$, respectively) obtained at the Hospital Sant Pau, Barcelona.

BACE-specific enzymatic activity assay

Tissues of human brain samples weighing 100-200 mg were homogenized with the proteoExtract ${ }^{\mathrm{TM}}$ Native Membrane Protein Extraction Kit (Calbiochem). BACE1 activity in human brain homogenates was measured as 
Table 1 Clinical and neuropathological data of ADAD patients from whom brain material was analyzed

\begin{tabular}{|c|c|c|c|c|c|c|c|c|c|}
\hline Case \# & Mutation & Gender & $\begin{array}{l}\text { Thal } \\
\mathrm{A} \beta \text { phase }\end{array}$ & $\begin{array}{l}\text { Braak } \\
\text { NF stage }\end{array}$ & $\begin{array}{l}\text { Age at } \\
\text { onset }\end{array}$ & $\begin{array}{l}\text { Age at } \\
\text { death }\end{array}$ & $\begin{array}{l}A P O E \\
\text { genotype }\end{array}$ & $\begin{array}{l}\text { PMI } \\
\text { (h) }\end{array}$ & $\begin{array}{l}\text { Effects on } \mathrm{A} \beta \\
\text { production }^{\mathrm{a}}\end{array}$ \\
\hline 1 & $A P P \mathrm{I} 716 \mathrm{~F}$ & M & 5 & VI & 31 & 36 & 33 & 15 & $\begin{array}{l}\mathrm{A} \beta 1-40 \downarrow \\
\mathrm{A} \beta 1-42 \uparrow \\
\mathrm{A} \beta 1-42 / \mathrm{A} \beta 1-40 \uparrow\end{array}$ \\
\hline 2 & $A P P \mathrm{~A} 713 \mathrm{~T}$ & M & 5 & VI & 49 & 56 & 33 & 16 & NA \\
\hline 3 & PSEN1 V89L & M & 5 & VI & 48 & 57 & 23 & 9.5 & NA \\
\hline 4 & PSEN1 E120G & M & 5 & VI & 34 & 44 & 33 & 5.5 & NA \\
\hline 5 & PSEN1 M139T & M & 5 & $\mathrm{~V}$ & 47 & 64 & 33 & 14.7 & $\mathrm{~A} \beta 1-42 / \mathrm{A} \beta$ tot $\uparrow$ \\
\hline 6 & PSEN1 M139T & M & 5 & VI & 48 & 57 & 33 & 15.2 & - \\
\hline 7 & PSEN1 M139T & M & 5 & VI & 45 & 53 & 33 & 5.3 & - \\
\hline 8 & PSEN1 P264L & $\mathrm{F}$ & 5 & VI & 45 & 56 & 44 & 6 & $\begin{array}{l}\mathrm{A} \beta 1-40=\mathrm{A} \beta 1-42 \uparrow \\
\mathrm{A} \beta 1-42 / \mathrm{A} \beta 1-40 \uparrow\end{array}$ \\
\hline 9 & PSEN1 P264L & M & 5 & VI & 53 & 60 & 34 & 7.2 & - \\
\hline 10 & PSEN1 L286P & $\mathrm{F}$ & 5 & $\mathrm{~V}$ & 35 & 56 & 33 & 5 & NA \\
\hline 11 & PSEN1 E280A & $\mathrm{F}$ & 5 & VI & 47 & 54 & 33 & 5.5 & $\begin{array}{l}\mathrm{A} \beta 1-40=\mathrm{A} \beta 1-42 \uparrow \\
\mathrm{A} \beta 1-42 / \mathrm{A} \beta 1-40 \uparrow\end{array}$ \\
\hline 12 & PSEN1 E280A & $\mathrm{F}$ & 5 & VI & 42 & 50 & 33 & 7.5 & - \\
\hline 13 & PSEN1 E280A & M & 5 & VI & 44 & 52 & 33 & 4.8 & - \\
\hline 14 & PSEN1 E280A & M & 5 & VI & 47 & 56 & 33 & 3.3 & - \\
\hline 15 & PSEN1 E280A & $\mathrm{F}$ & 5 & VI & 49 & 62 & 33 & 4 & - \\
\hline 16 & PSEN1 E280A & $\mathrm{F}$ & 5 & VI & 37 & 47 & 33 & 2.3 & - \\
\hline 17 & PSEN1 E280A & M & 5 & VI & 49 & 55 & 44 & 2.8 & - \\
\hline 18 & PSEN1 E280A & $\mathrm{F}$ & 5 & VI & 50 & 60 & 33 & 2.8 & - \\
\hline
\end{tabular}

$N A$ not available, $N F$ neurofibrillary, $M$ male, $F$ female

${ }^{a}$ Source: http://www.molgen.ua.ac.be/ADMutations

previously described $[19,20]$. This BACE activity assay was based on an antibody capture assay in which activity was measured via fluorescent emission after the cleavage of a $\beta$-secretase substrate $[19,20]$. To avoid the detection of other $\beta$-secretase activities, BACE was first captured via its C-terminal domain with anti-BACE1 antibody MAB5308 (mouse monoclonal anti-BACE, Chemicon) raised against BACE1 epitopes different from BACE2. Briefly, 96-well plates were coated overnight with the capture antibody MAB5308 at a dilution of 1:1,000 in $100 \mathrm{mM}$ carbonate buffer at $4{ }^{\circ} \mathrm{C}$. The plates were washed three times with phosphate-buffered saline (PBS, pH 7.0), and then blocked with a blocking reagent (25\% BlockAce; Dai-Nippon) for $6 \mathrm{~h}$. The samples $(50 \mu \mathrm{l}$ of $0.004 \mathrm{wt} / \mathrm{vol})$ were added to the wells containing $50 \mu$ of Superblock ${ }^{\circledR}$ blocking buffer (Pierce) in PBS and incubated for $1 \mathrm{~h}$ at $37^{\circ} \mathrm{C}$. The plates were washed 6 times with PBS, and the enzymatic reaction was carried out by incubation with $10 \mu \mathrm{M}$ of the fluorogenic $\beta$-secretase substrate Arg-Glu (5-[aminoethyl] aminonaphthalene sulfonate [EDANS])Glu-Val-Asn-Leu-Asp-Ala-Glu-Phe-Lys (4'-dimethylaminoazo-benzene-4-carboxylate[DABCYL])-Arg (Calbiochem) in acetate buffer at $\mathrm{pH} 4.1$, which is optimal for BACE activity
$[19,20]$. Samples were incubated overnight at $37{ }^{\circ} \mathrm{C}$, and the enzymatic reaction was measured using a Victor 3 Wallac microplate reader (Perkin-Elmer).

BACE activity in human CSF was measured by incubating $10 \mu \mathrm{l}$ of sample with $50 \mu \mathrm{l}$ of BACE substrate $(40 \mu \mathrm{M})$ overnight at $37^{\circ} \mathrm{C}$ in acetate buffer with $100 \mathrm{mM}$ sodium chloride ( $\mathrm{pH} 4.1$ ) containing $0.025 \%$ BSA [60]. Fluorescence was measured at different time points with a Victor3 Wallac microplate reader with an excitation wavelength at $355 \mathrm{~nm}$ and emission wavelength at $486 \mathrm{~nm}$. The concentration of BACE substrate used was that which best differentiated serial CSF dilutions over different time points. The enzymatic activity was calculated as $\Delta \mathrm{UF} / \mathrm{min}$ from the linear part of the reaction (between 2 and $24 \mathrm{~h}$ ). The activity was completely inhibited by a BACE1 inhibitor verifying the specificity of the assay. The intra-assay and inter-assay coefficients of variation were 1.2 and $5.8 \%$, respectively.

\section{BACE1 protein, $\operatorname{sAPP} \alpha, \operatorname{sAPP} \beta$ and APP $\beta$-CTF assays}

BACE1 protein, $\operatorname{sAPP} \alpha, \operatorname{sAPP} \beta$, and APP $\beta$-CTF levels were measured in human brain samples or CSF using 
Table 2 Clinical and demographic data from PSEN1 mutations carriers from whom CSF was analyzed
The age has been omitted in presymptomatic mutation carriers to protect confidentiality

MMSE Mini-Mental State Examination, $N A$ not available

${ }^{a}$ Source: http://www.molgen. ua.ac.be/ADMutations

\begin{tabular}{|c|c|c|c|c|c|}
\hline Group & $\begin{array}{l}\text { PSEN1 } \\
\text { mutation }\end{array}$ & Age (years) & $\begin{array}{l}\text { MMSE } \\
\text { score }\end{array}$ & $\begin{array}{l}\text { CSF A } \beta 42 \\
\text { levels }(\mathrm{pg} / \mathrm{ml})\end{array}$ & $\begin{array}{l}\text { Effects on } \\
\mathrm{A} \beta \text { production }^{\mathrm{a}}\end{array}$ \\
\hline \multicolumn{6}{|c|}{ Healthy controls } \\
\hline 1 & - & 25.1 & 29 & 667 & - \\
\hline 2 & - & 35.4 & 29 & 647 & - \\
\hline 3 & - & 34.7 & 30 & 691 & - \\
\hline 4 & - & 38.8 & 29 & 578 & - \\
\hline 5 & - & 51.7 & 29 & 430 & - \\
\hline 6 & - & 43.8 & 29 & 734 & - \\
\hline 7 & - & 42.3 & 28 & 769 & - \\
\hline \multicolumn{6}{|c|}{ Presymptomatic PSEN1 mutation carriers } \\
\hline 8 & M139T & - & 30 & 822 & $\mathrm{~A} \beta 1-42 / \mathrm{A} \beta$ tot $\uparrow$ \\
\hline 9 & M139T & - & 30 & 753 & - \\
\hline 10 & M139T & - & 28 & 655 & - \\
\hline 11 & M139T & - & 29 & 505 & - \\
\hline 12 & $\mathrm{~K} 239 \mathrm{~N}$ & - & 29 & 1091 & NA \\
\hline \multicolumn{6}{|c|}{ Symptomatic PSEN1 mutation carriers } \\
\hline 13 & L235R & 46 & 11 & 279 & NA \\
\hline 14 & L282R & 46.3 & 22 & 199 & NA \\
\hline 15 & L286P & 37.3 & 28 & 166 & NA \\
\hline 16 & L286P & 42.6 & 24 & 163 & NA \\
\hline 17 & L286P & 44.7 & 24 & 165 & NA \\
\hline
\end{tabular}

commercial kit assays (IBL). These assays are based on a solid-phase sandwich ELISA using specific anti-BACE or anti-APP antibodies. For sAPP $\beta$ levels the cross-reactivity with human $\operatorname{sAPP} \beta-\mathrm{Sw}$ and human $\operatorname{sAPP} \alpha$ is 0.25 and $1.41 \%$, respectively, and for APP $\beta$-CTF levels the crossreactivity with human $\operatorname{sAPP} \beta$ and human $\operatorname{sAPP} \alpha$ is $\leq 0.1 \%$. BACE1 protein and APP $\beta$-CTF levels were measured in the membrane brain fraction while sAPP $\alpha$ and sAPP $\beta$ levels were measured in CSF.

\section{Immunohistochemistry procedures}

Detailed neuropathological studies were performed on multiple formalin-fixed, paraffin-embedded samples, as previously described [23]. For immunohistochemistry, dewaxed 5- $\mu \mathrm{m}$-thick sections that included hippocampus, parahippocampal and temporo-occipital gyrus were immunostained in an automated stainer (DAKO Autostainer Plus) using the following antibodies: a rabbit anti-APP C-terminal (Sigma-Aldrich) recognizing the C-terminus (amino acids 676-695) of human APP 695, APP751 and APP770 at a dilution of 1:1,500; a mouse anti-APP N-terminal (Millipore, clone $22 \mathrm{C} 11$ ) antibody at a dilution of $1: 50$; and a mouse monoclonal anti- $\beta$ A4-amyloid (DAKO, clone 6F/3D) antibody at a dilution of 1:400. To further evaluate the neuritic component of amyloid plaques, anti-ubiquitin (DAKO, polyclonal) and anti-hyperphosphorylated tau (Thermo Scientific, mc, clone AT8) antibodies were used at a dilution of
1:400 and 1:200, respectively. APP-immunoreactive structures were assessed semiquantitatively as follows: + mild (1-10 conglomerates of dystrophic neurites in one visual field using a $10 \times$ objective), ++ moderate (from 10 to 20 neuritic conglomerates), +++ abundant $(>20$ neuritic conglomerates), similar to the assessment of $\beta$-amyloid deposits [1]. For antigen retrieval, sections were immersed for $5 \mathrm{~min}$ in 98-100 \% formic acid and heated for $20 \mathrm{~min}$ in a pressure cooking oven in $0.1 \mathrm{M}$ sodium citrate buffer at $\mathrm{pH}$ 6.0. The reaction was visualized with $0.05 \%$ diaminobenzidine and $0.01 \% \mathrm{H}_{2} \mathrm{O}_{2}$.

\section{Western blot}

Human brain homogenates were electrophoresed in 5-16\% Tris-Tricine gels, transferred to $0.2 \mu \mathrm{m}$ nitrocellulose membranes, and detected by immunoblotting with a rabbit anti-APP C-terminal (1:2,000; Sigma-Aldrich), a rabbit monoclonal N-terminus anti-BACE (D10E5, 1:1,000; Cell Signaling), a mouse monoclonal C-terminus anti-BACE (MAB5308, 1:1,000; Chemicon) or mouse monoclonal anti-tubulin (1:20,000; Sigma-Aldrich) antibodies. Specificity of the anti-BACE antibodies was verified by Western blot using brain homogenates from P7 BACE1-/- mice (a kind gift from Bart De Strooper [16]; Fig. S1). Incubation with primary antibodies was followed by detection with IR-fluorescent-conjugated antibody (LI-COR Biosciences). All blots were quantified by 
densitometric analysis and normalized to tubulin (Odyssey software, LI-COR Biosciences).

\section{APOE genotyping}

APOE genotype was determined as previously described [23].

\section{Statistical analysis}

Non-parametric statistical analysis (Kruskal-Wallis) was performed to analyze differences in BACE1, APP $\beta$-CTF, $\operatorname{sAPP} \beta$ protein levels and BACE activity. Correlation analysis between age and CSF BACE1 activity, APP $\beta$-CTF, and $\operatorname{sAPP} \beta$ protein levels was performed using the Spearman's Rho test. Statistical significance for all the analyses was set at $5 \%(\alpha=0.05)$. All data were analyzed using the Statistical Package for the Social Sciences (SPSS) version 20.0.

\section{Results}

BACE1 protein levels and activity are elevated in SAD but not in ADAD brains

We first examined the initial proteolytic cleavage involved in $\mathrm{A} \beta$ generation, performed by BACE1 [37]. BACE1

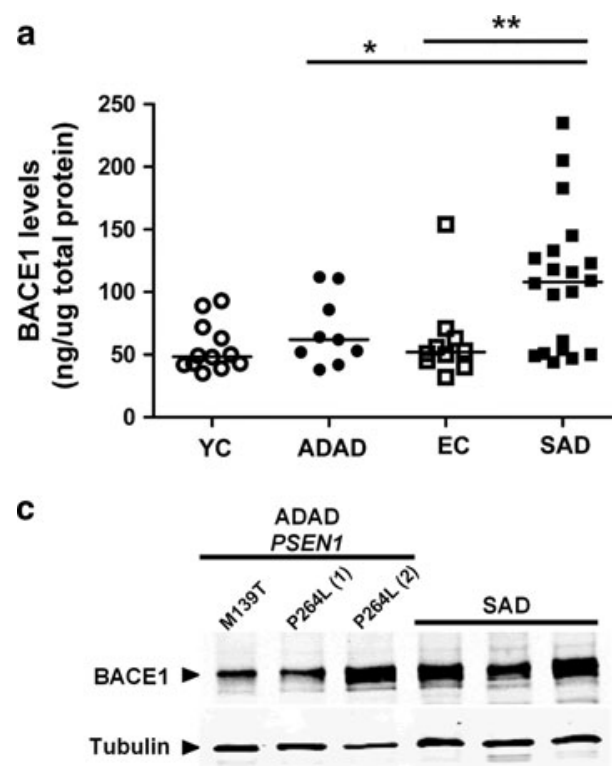

Fig. 1 Brain BACE1 protein levels and activity in ADAD, SAD patients and controls. BACE1 protein levels and activity were measured in brain homogenates from ADAD and SAD patients, and from young (YC) and elderly (EC) controls. There was an increase in BACE1 protein levels $(\mathbf{a} * *=0.01)$ and activity $(\mathbf{b} * p=0.04)$ in the frontal cortex of SAD cases compared to age-matched elderly controls. No differences were detected between ADAD cases and agematched controls in either brain BACE1 protein levels or activity protein levels and activity were measured in homogenates from the frontal cortex from ADAD cases, and compared with those from SAD cases and age-matched controls. Across the entire group $(n=51)$ BACE1 protein levels and activity positively correlated with age $(\rho=0.3$, $p=0.03$ and $\rho=0.28, p=0.04$, respectively). Consistent with other studies [19], there was no association of BACE1 protein levels or activity with PMI, gender or APOE genotype. BACE1 protein levels correlated with BACE1 activity in the entire sample $(\rho=0.29$, $p=0.04)$. No differences were detected in either brain BACE1 protein levels or activity between ADAD cases and age-matched controls (Fig. 1a, b; $p=0.91$ and $p=0.42$, respectively). Consistent with previous reports $[19,27,58]$, we found an increase in BACE1 protein levels (1.91-fold, Fig. 1a; $p=0.01$ ) and activity (1.76fold, Fig. $1 b ; p=0.04$ ) in the frontal cortex of SAD cases when compared to age-matched controls. There was a significant increase in BACE1 protein levels $(p=0.03)$ but not in BACE1 activity $(p=0.12)$ in SAD relative to ADAD cases. The levels of BACE1 protein in brain homogenates were also analyzed by Western blot using the specific anti-BACE1 antibody D10E5 (Fig. S1). These analyses confirmed the increase in BACE1 protein expression in SAD relative to controls and ADAD, as well as the lack of differences between ADAD and controls (Fig. 1c, d).

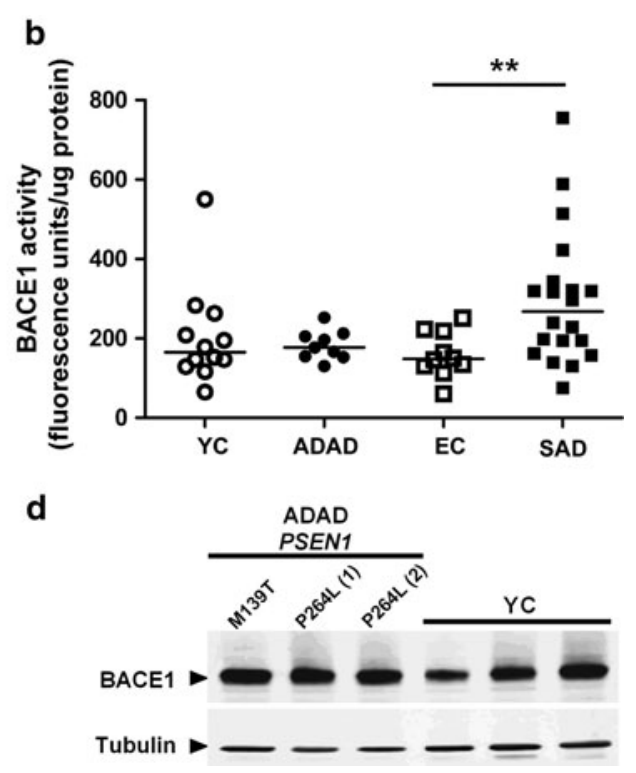

( $p=0.91$ and $p=0.42$, respectively). There was a significant increase in BACE1 protein levels $\left(\mathbf{a}^{*} p=0.03\right)$ but not in BACE1 activity (b, n.s., $p=0.12$ ) in SAD relative to ADAD cases. Western blot analyses using the BACE-specific antibody BC05 confirmed the increased in BACE expression in SAD compared to ADAD (c) and the lack of differences between ADAD and controls (d). Representative blots are shown 
CSF BACE1 expression and activity are not elevated in PSEN1 mutation carriers or in SAD dementia cases

We next tested whether an increase in BACE1 expression or activity was present in ADAD in the CSF. We obtained CSF samples from a cohort of subjects recruited from a genetic counseling program for familial dementias [17, 18]. We used a fluorogenic CSF BACE1 enzymatic activity assay to measure BACE1 activity in CSF samples from 17 PSEN1 mutation carriers and non-carriers (Table 2), subjects with SAD dementia $(n=32)$ and healthy controls $(n=11)$. CSF BACE1 activity did not correlate with age, MMSE score or CSF A $\beta 42$ levels in the entire sample ( $n=60$ ) or with the adjusted age in PSEN1 mutation carriers $(n=10)$. When analyzed according to clinical or mutation status, no differences in CSF BACE1 activity were detected among PSEN1 mutation carriers and nonmutation carriers $(p=0.85)$ or between SAD cases and controls ( $p=0.1$; Fig. 2a). As an additional measure of APP processing, we analyzed CSF levels of $\operatorname{sAPP} \beta$, a soluble fragment generated by BACE cleavage. Levels of $\operatorname{sAPP} \beta$ correlated positively with age $(\rho=0.279$; $p=0.03$ ) but not with MMSE score or CSF A $\beta 42$ levels in the entire sample. We found no differences in CSF sAPP $\beta$ levels between PSEN1 mutation carriers and non-mutation carriers ( $p=0.85$; Fig. $2 b$ ) or between SAD dementia cases and age-matched controls ( $p=0.12$; Fig. $2 b$ ). CSF BACE1 activity and $\operatorname{sAPP} \beta$ levels showed a positive correlation in the entire subject sample $(\rho=0.501$, $p<0.001$; Fig. 2c). Almost identical results were found when CSF $\operatorname{sAPP} \alpha$ levels were measured (Fig. 2d). This is not surprising since CSF $\operatorname{sAPP} \beta$ and $\operatorname{sAPP} \alpha$ levels showed

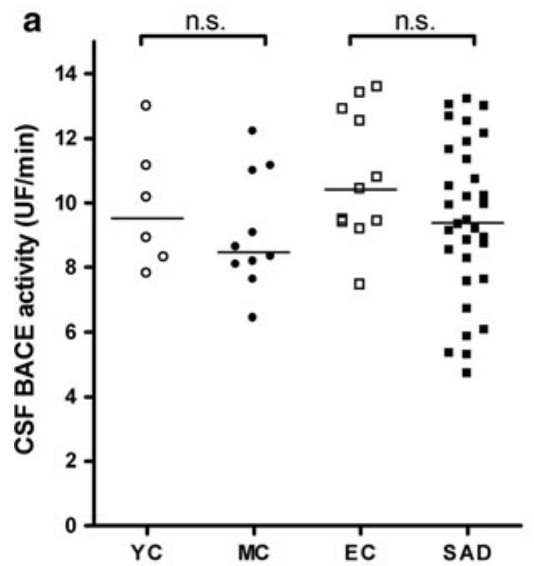

b

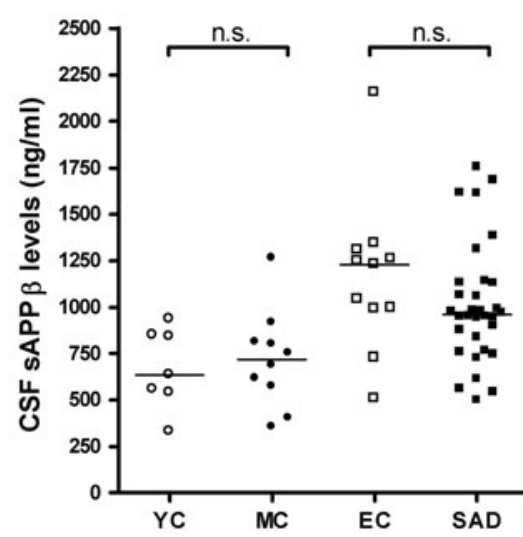

e

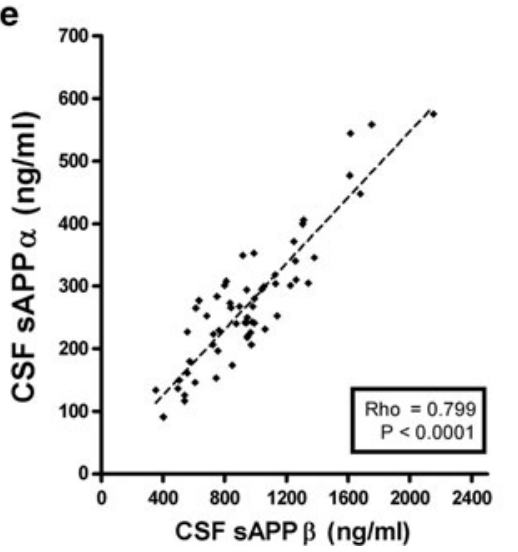

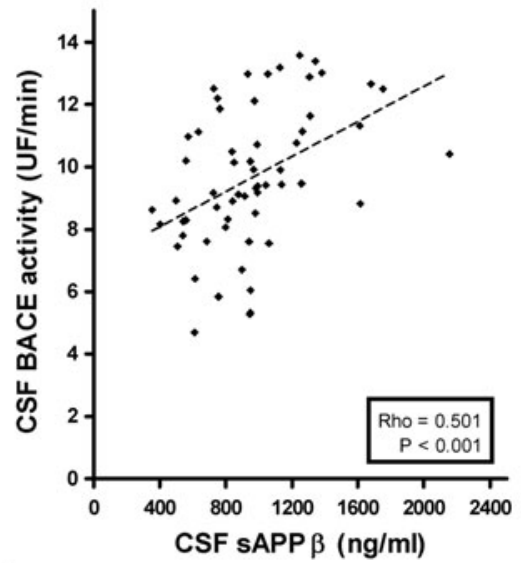

f

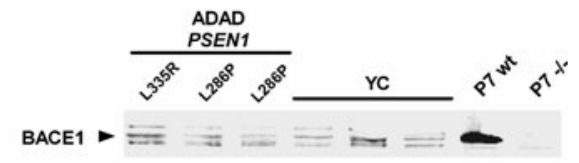

Fig. 2 CSF BACE1 activity in PSEN1 mutation carriers, SAD patients and controls. a CSF BACE1 activity was measured in nonmutation carriers controls $(Y C)$, PSEN1 mutation carriers $(M C)$, elderly controls $(E C)$ and SAD patients. No differences were found between groups in CSF BACE1 activity. b CSF sAPP $\beta$ levels were determined in YC, MC, EC and SAD patients. No differences were found between SAD cases and age-matched controls or between MC and YC. c CSF BACE1 activity and $\operatorname{sAPP} \beta$ levels showed a positive correlation in the entire subject sample $(\rho=0,501, p<0.001)$. d CSF $\mathrm{sAPP} \alpha$ levels were determined in YC, MC, EC and SAD patients. No differences were found between SAD cases and agematched controls or between MC and YC. e CSF $\operatorname{sAPP} \beta$ and $\operatorname{sAPP} \alpha$ levels showed a strong positive correlation in the entire subject sample $(\rho=0,799, p<0.0001)$. f Western blot analyses of BACE1 protein levels using the specific anti-BACE1 antibody D10E5 showed no differences between PSEN1 mutation carriers and non-carriers $(Y C)$. The specificity of the D10E5 was determined by using brain samples from 7-day-old (P7) wt and BACE 1-/- mice (Fig. S1). A representative blot is shown 
a strong positive correlation in the entire subject sample ( $\rho=0.799, p<0.0001 ;$ Fig. $2 \mathrm{e})$, as in previously reported studies $[33,59]$. To examine whether there was any difference in CSF BACE1 protein levels, Western blotting was carried out using the specific anti-BACE1 antibody D10E5 and no differences were detected between PSEN1 mutation carriers and non-mutation carriers (Fig. 2f). Overall, no changes in CSF BACE1 activity or expression could be detected in subjects with PSEN1 mutations or SAD compared to age-matched controls.

\section{Brain APP $\beta$-CTF levels are higher in ADAD than SAD}

Using ELISA, we then determined the levels of APP $\beta$-CTF, a protein fragment generated from full-length APP in frontal cortex brain homogenates obtained from patients with ADAD, SAD and controls. The APP $\beta$-CTF fragment is generated by BACE and processed by $\gamma$-secretase to release $\mathrm{A} \beta$ peptides [37]. We found that $\mathrm{ADAD}$ cases showed a prominent APP $\beta$-CTF accumulation when compared to age-matched controls and to SAD cases (both $p<0.001$, Fig. 3a). SAD cases did not show statistically significant higher APP $\beta$-CTF levels than age-matched controls by ELISA ( $p=0.47$, Fig. $3 \mathrm{a}$ ), despite being elevated by Western blot (Fig. S2). No differences were found between young and elderly controls. The levels of APP $\beta$-CTF were not influenced by age, gender or APOE genotype. The results of the ELISA were confirmed by Western blot analysis in our subject sample and in patients with the E280A PSEN1 mutation (Fig. 3b-d; Fig. S2). Among ADAD cases, the APP A713T and some PSEN1 mutations (P264L, P286P) displayed higher levels of APP C-terminal fragments than others (M139T, V89L).

APP-immunoreactive dystrophic neurites and aggravated neuritic component in ADAD

Since our biochemical data indicated elevated APP $\beta$-CTF levels in ADAD compared to SAD and controls, we next evaluated the distribution of APP accumulation. We performed immunohistochemical studies on brain sections from ADAD cases using either an anti-APP C-terminal or an anti-APP $\mathrm{N}$-terminal antibody. As previously described [13,30,43], we confirmed that antibodies rose against APP labeled dystrophic neurites of senile plaques in SAD using both, anti-C-terminal and anti-N-terminal antibodies. Both APP antibodies also detected APP epitopes in dystrophic neurites of senile plaques in ADAD(Fig.S3).Semiquantitativeassessmentoftheneuritic component associated to amyloid plaquesin parahippocampal and temporo-occipital cortices revealed that patients with ADAD had a more prominent neuritic component than those with SAD (Fig. 4; Table 3)independently of the number of $\mathrm{A} \beta$ plaques. This was also observed using anti-ubiquitin (Fig. 4) and anti-phosphorylated tau antibodies (Fig. S3 and data not shown). Cases with predominantcotton-woolplaques(PSEN1 P264L, PSEN1 L286P) showed fewer APP-immunoreactive dystrophic neurites than ADAD cases with neuritic plaques (Fig. 4). a

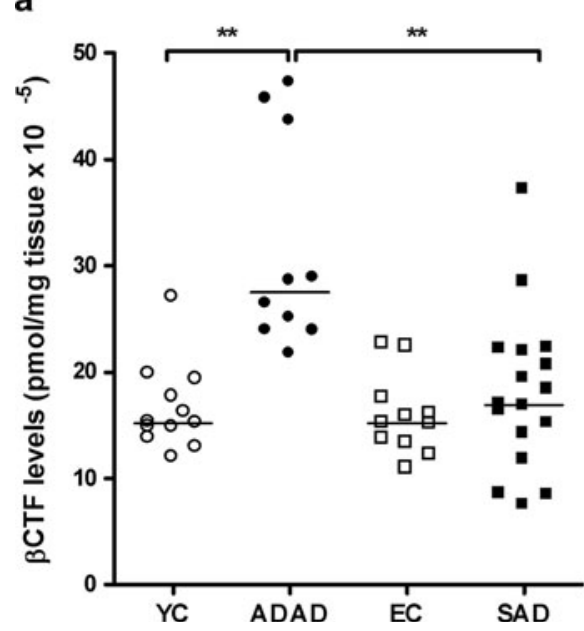

b
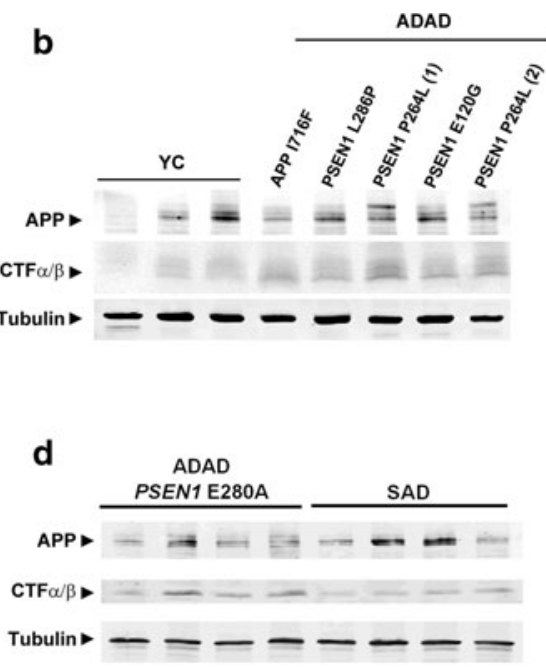

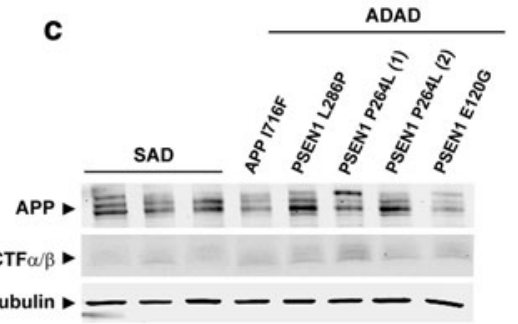

e

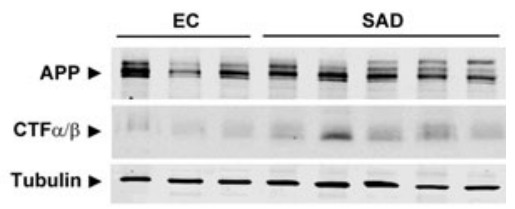

Fig. 3 Brain APP $\beta$-CTF levels are elevated in ADAD. APP $\beta$-CTF levels were measured in membrane fractions in brain homogenates from ADAD, SAD and controls (a). ADAD cases showed higher APP $\beta$-CTF levels than age-matched controls and SAD $(* * p<0.01)$. These differences were confirmed by Western blot in samples from patients with ADAD, SAD and controls. APP CTF accumulation was observed in ADAD cases compared to age-matched controls (b) and to SAD cases (c, d). APP CTF accumulation was also observed by Western blot in SAD cases compared to controls despite the fact that it did not reach statistical significance in the ELISA assay (e) 


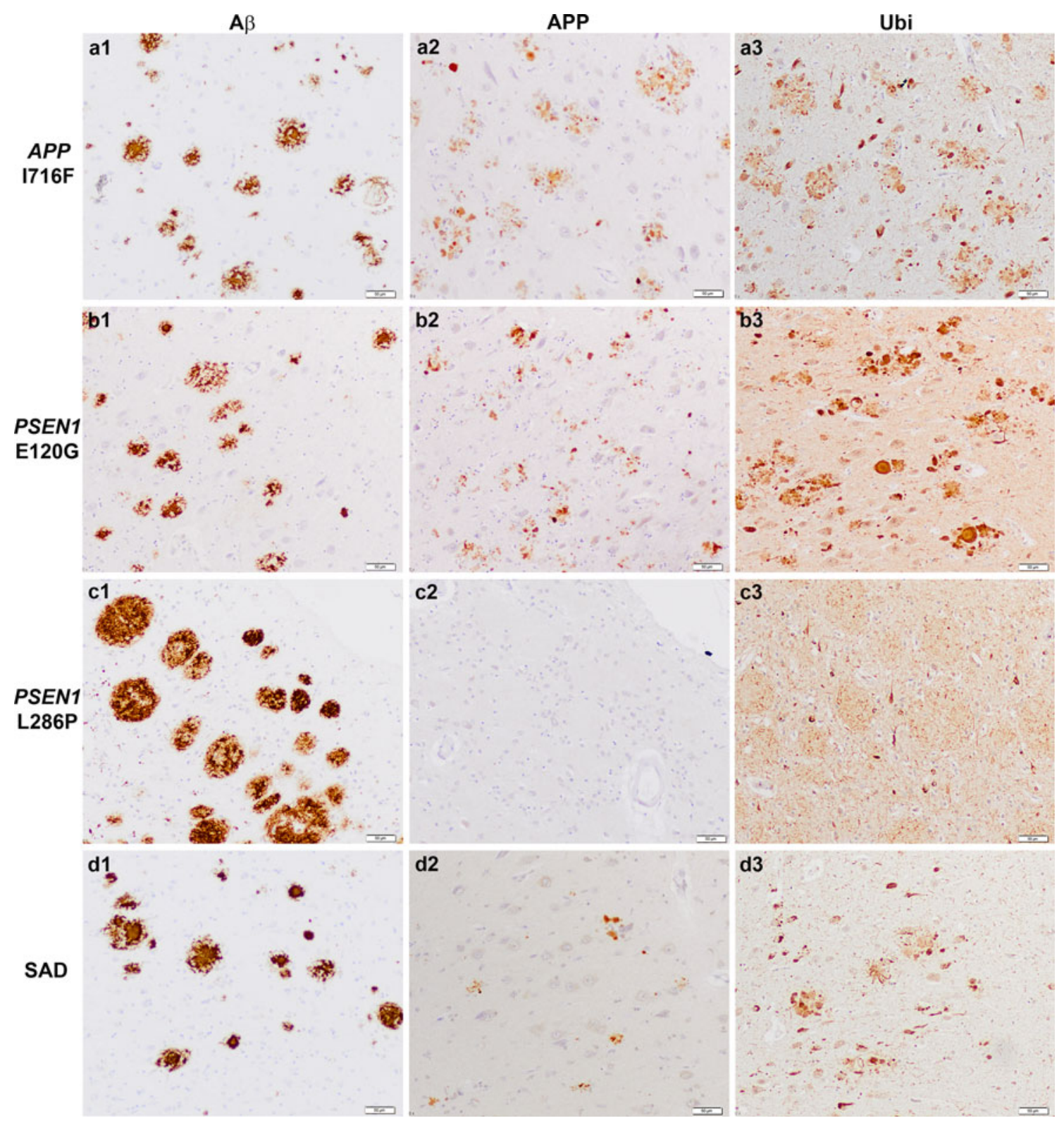

Fig. 4 APP accumulates in dystrophic neurites in ADAD. Immunohistochemistry for $\mathrm{A} \beta$, APP and ubiquitin on representative brain sections from ADAD subjects carrying the APP I716F (a1-a3), the PSEN1 E120G (b1-b3), PSEN1 L286P (c1-c3) mutations and from one patient with SAD (d1-d3). Note frequent A $\beta$ deposits, APP- and ubiquitin-positive bulbous dystrophic neurites in subjects with $A P P$

\section{Discussion}

The main finding in the current study is that ADAD and SAD display distinct profiles in BACE protein and activity, and in APP $\beta$-CTF levels in the brain. While no apparent increase in brain BACE1 protein levels or activity was observed in ADAD, both were clearly elevated in SAD. Accumulation of APP $\beta$-CTF was higher in the brain in ADAD than in SAD and controls. No changes in BACE
I716F and PSEN1 E120G mutations in contrast to the nearly lack of APP-positive neurites in subject with the PSEN1 L286P mutation where cotton-wool plaques predominate. In the latter case, ubiquitin immunostains delicate intermingled neurites (c3). In the SAD case, abundant mature A $\beta$ deposits (d1) contrast with the few APP-(d2) and prominent ubiquitin-immunoreactive dystrophic neurites. Bar $50 \mu \mathrm{m}$ measures were observed in the CSF between ADAD and SAD.

Research in ADAD has been instrumental as a model to understand the pathogenesis of SAD and to guide the current development of anti-amyloid strategies. The mainstream paradigm claims that $\mathrm{ADAD}$ and $\mathrm{SAD}$ share similar clinical and pathological phenotypes as well as common mechanisms of disease, irrespective of the initiation factors [6, 54]. However, very few studies have 
Table 3 Relationship between dystrophic neurites and $\mathrm{A} \beta$ deposits in ADAD cases

\begin{tabular}{|c|c|c|c|}
\hline Case & Mutation & $\begin{array}{l}\text { APP-immunoreactive } \\
\text { dystrophic neurites }\end{array}$ & $\mathrm{A} \beta$ deposits \\
\hline 1 & $A P P \mathrm{I} 716 \mathrm{~F}$ & +++ & Abundant mature and primitive plaques \\
\hline 2 & $A P P \mathrm{~A} 713 \mathrm{~T}$ & +++ & $\begin{array}{l}\text { Abundant mature and primitive plaques. } \\
\text { Few diffuse plaques }\end{array}$ \\
\hline 3 & PSEN1 V89L & +++ & Abundant mature and primitive plaques \\
\hline 4 & PSEN1 E120G & +++ & Abundant mature and primitive plaques \\
\hline 5 & PSEN1 M139T & ++ & More primitive plaques than mature plaques \\
\hline 6 & PSEN1 M139T & ++ & Abundant mature and primitive plaques \\
\hline 7 & PSEN1 M139T & +++ & Abundant mature and primitive plaques \\
\hline 8 & PSEN1 P264L & + & Predominantly cotton-wool plaques \\
\hline 9 & PSEN1 P264L & ++ & $\begin{array}{l}\text { Abundant cotton-wool plaques mixed } \\
\text { with mature and primitive plaques }\end{array}$ \\
\hline 10 & PSEN1 L286P & + & Predominantly cotton-wool plaques \\
\hline
\end{tabular}

investigated the differences in APP processing between ADAD and SAD in the human CNS to support this view. Previous studies have mainly focused on $\mathrm{A} \beta$ isoforms, tau or p-tau in the CSF $[5,44,46,49]$ or $\mathrm{A} \beta$ isoforms in human brain $[45,49]$. The findings suggest a specific CSF profile of $\mathrm{A} \beta$ isoforms in $\mathrm{ADAD}$, with low levels of $\mathrm{A} \beta 1-37, \mathrm{~A} \beta 1$ 38, $\mathrm{A} \beta 1-39$ and $\mathrm{A} \beta 1-42$ compared with $\mathrm{SAD}[5,44]$. Whether other relevant aspects of APP processing differ between ADAD and SAD remains unknown.

BACE1 is a type-I transmembrane protease highly expressed in neurons [11]. Previous studies have demonstrated that BACE1 protein levels and activity are elevated approximately twofold in the brain of SAD patients $[9,19$, $27,58]$, suggesting that this feature might initiate or contribute to brain $\mathrm{A} \beta$ accumulation [34]. Our data confirmed the increased BACE1 levels and activity in SAD brains, but no increase could be detected in ADAD cases compared to age-matched controls. Although the increase in brain BACE1 protein levels in SAD relative to ADAD cases might reflect a difference in chronological age between groups, the increment in brain BACE1 activity and protein levels in SAD compared to age-matched controls suggests a disease-specific effect. Our data differ from the only previous study that had examined BACE1 expression or activity in ADAD brains [22], where the authors reported an increase in BACE1 mRNA levels and activity in 11 ADAD cases carrying 10 different PSENI mutations. The strengths of the current study are the use of age-matched controls without any brain lesion, the selection of a region in which elevated BACE1 activity had been previously detected in SAD [34], and the investigation of CSF samples obtained from PSEN1 mutation carriers. Our findings lend support to other studies that reported no change in BACE1 expression or activity in either APP or PS1 mutant-transfected cells or APP $\times$ PS1-transgenic mice [4, 20, 34].
In contrast with our findings in human brain, we did not find any differences in CSF BACE activity or expression, or in sAPP $\beta$ levels between groups. The lack of increase in CSF BACE1 activity or sAPP $\beta$ levels in cases with SAD dementia compared to healthy controls is in agreement with most recent studies [48, 59]. The present data together with previous work $[48,59,60]$ suggest that BACE1 activity may become elevated at the stage of mild cognitive impairment, and then decrease over time as disease progresses [48]. Our data obtained in patients with SAD dementia also indicate that CSF BACE1 activity does not parallel brain BACE1 activity, at least in the advanced stage of the disease. While BACE1 activity and protein levels in the brain tend to increase in late-stage $A D$, BACE1 activity in the CSF would stabilize or even decrease, perhaps as a result of a reduction in global neuronal function [48]. More generally, this observation indicates that CSF may not accurately reflect the changes in the local intracellular or extracellular environment [10,57]. Taken together, our results indicate that brain BACE1 upregulation is characteristic of $\mathrm{SAD}$, but is not a salient feature in many ADAD-associated mutations. Previous studies [26, 27, 47] have shown that increased BACE1 expression in SAD is due to post-translational regulation mechanisms and that BACE1 mRNA levels are unchanged. One possible explanation is that the increase in BACE1 in SAD results from the interaction of Alzheimer pathology with diverse factors associated to aging, such as oxidative stress, inflammatory changes or microRNA dysregulation, conditions known to increase BACE1 expression and activity in cell culture [12, 26, 50, 55].

The lack of increase in BACE1 in ADAD has clinical implications as BACE1 has become an attractive drug target for AD intervention [11]. Although inhibitor development has proved to be highly challenging, some 
promising BACE1 inhibitors as well as other strategies, such as immunization with anti-BACE1 antibodies, have been developed [11]. The lack of increase in brain or CSF BACE1 expression or activity in ADAD in our study suggests that BACE1 is a less attractive target for families with ADAD than for patients with SAD. Nonetheless, it is still possible that BACE1 inhibition may prove to be effective as a preventive therapy in subjects with $A P P$ or PSEN1 mutations. This is a relevant and timely topic since clinical trials in ADAD are imminent.

Another important finding derived from our study is the higher accumulation of APP $\beta$-CTFs in the brain of ADAD cases than in SAD patients and controls. The APP $\beta$-CTF fragment is generated by BACE and processed by $\gamma$-secretase to release $\mathrm{A} \beta$ peptides [37]. The main explanation for the APP $\beta$-CTF accumulation in SAD has been the overproduction due to increased BACE1 protein levels and activity [58]. However, the lack of elevated BACE1 in ADAD points to other underlying mechanisms. It has been suggested that PSEN mutations alter the conformation of the $\gamma$-secretase complex [7, 14]. This change could be a plausible mechanism by which PSEN mutations lead to $\gamma$-secretase dysfunction and the formation of longer $\mathrm{A} \beta$ peptides in ADAD [7, 15]. Since APP $\beta$-CTF are processed by $\gamma$-secretase, it is possible that elevated APP $\beta$-CTF may be the result of a dysfunctional $\gamma$-secretase. A recent study has shown that ADAD-associated mutations do not consistently affect kinetic activity [15] excluding the possibility that mutations inhibit $\gamma$-secretase. However, conformational changes in $\gamma$-secretase may subtly slow substrate processivity which could increase $\beta$-CTF in ADAD. Other possible mechanisms underlying APP $\beta$-CTF accumulation in ADAD include impaired macroautophagy as it has been shown that APP $\beta$-CTF is rapidly cleared by autophagy under physiological conditions [56]. In any case, the accumulation of APP CTFs has been shown to be neurotoxic by itself [29, 31, 39, 42]. This phenomenon has also been observed in wild-type mice or transgenic APP mouse models after treatment with classical $\gamma$-secretase inhibitors $[8,40]$ or after inactivation of PSEN1 [51]. In both these situations, APP CTFs accumulate at the presynaptic terminals, likely impairing synaptic plasticity and long-term memory [40, 51]. Interestingly, APP CTF accumulation has been postulated, together with inhibition of Notch processing [15], as a possible mechanism underlying cognitive side effects in patients with AD treated with the $\gamma$-secretase inhibitor semagacestat $[8,37]$. Although the precise cause of APP CTF accumulation in ADAD deserves further investigation, it is likely that this feature acts as an active component of the disease that may contribute to the metabolic and cytoskeletal derangement and neurodegeneration.

Our findings also demonstrate that the neuritic component is more prominent in ADAD cases than in SAD. It has previously been shown that full-length APP accumulates in dystrophic neurites in $\operatorname{SAD}[13,21,28,30,43]$ and that this accumulation is an early event that occurs prior to tau accumulation [13]. Our results extend these findings to ADAD and show a more severe neuritic component in ADAD than in SAD. The wide variety of neuronal proteins found in $\mathrm{AD}$ in dystrophic neurites has been increasingly recognized as a failure of the autophagic-lysosomal pathway [41]. In addition, it has been shown that PS1 is essential for lysosomal proteolysis and autophagy and that PS1-null or PS-ADAD fibroblasts display marked autophagy impairment $[32,41]$. This defect could account for our observation of numerous and enlarged dystrophic neurites in ADAD as compared to SAD. Finally, the contribution of APP-immunoreactive dystrophic neurites to parenchymal amyloid deposition seems unlikely because at least one half of diffuse plaques, which may represent the earliest stage of the amyloid plaque, do not contain APP-immunoreactive neuritic profiles $[13,30]$ and we did not observe APP epitopes in dystrophic neurites in ADAD cases with cottonwool plaques.

The main limitation in the present study is that as only the frontal cortex region was analyzed, we cannot exclude the possibility that other brain areas might have shown different results. Besides, our study only included cases carrying either two APP mutations or nine PSEN mutations, and whether our findings are generalizable to all ADAD cases requires further investigation. Finally, it is worth mentioning that the two APP mutations investigated herein are close to the $\gamma$-secretase cleavage site, and they were predicted to affect $\gamma$-secretase processing on a similar way to PSEN mutations. It is possible that other APP mutations located outside of the $\gamma$-secretase cleavage site may have shown different effects.

In summary, the data presented herein reinforce the different physiopathological mechanisms underlying the $\mathrm{A} \beta$ production/clearance imbalance in SAD and ADAD. These differences in APP processing may contribute to explain the lack of alignment between studies in humans and in $\mathrm{AD}$ animal models. A deeper understanding of the common and divergent fundamental pathogenic mechanisms in ADAD and SAD is needed to fine-tune and accelerate drug development in AD.

Acknowledgments This work was supported by the Instituto de Salud Carlos III (FIS/PI100018 to A. Lleó and FIS/PI080036 to R. Sánchez-Valle), CIBERNED (A. Lleó and I. Ferrer), and Joint Programming for Neurodegenerative Diseases-BIOMARKAPD (A. Lleó and JL. Molinuevo). The authors would like to thank all brain donors and their relatives for generous brain donation for research, and the brain banks from the Hospital Universitari de Bellvitge, Biobanc-Hospital Clinic-IDIBAPS and the Antioquia University. The authors are indebted to Dr. Maria Jesús Rey for neuropathological studies, Mrs. Rosa Rivera, Sara Charif, Nuria Setó, Laia Muñoz and Marta Rodríguez for technical assistance, and to 
Carina Antiga and Carolyn Newey for administrative support and editorial assistance, respectively.

Conflict of interest The authors declare that they have no conflict of interest.

Open Access This article is distributed under the terms of the Creative Commons Attribution License which permits any use, distribution, and reproduction in any medium, provided the original author(s) and the source are credited.

\section{References}

1. Alafuzoff I, Pikkarainen M, Arzberger T, Thal DR, Al-Sarraj S, Bell J, Bodi I, Budka H, Capetillo-Zarate E, Ferrer I, Gelpi E, Gentleman S, Giaccone G, Kavantzas N, King A, Korkolopoulou P, Kovacs GG, Meyronet D, Monoranu C, Parchi P, Patsouris E, Roggendorf W, Stadelmann C, Streichenberger N, Tagliavini F, Kretzschmar H (2008) Inter-laboratory comparison of neuropathological assessments of beta-amyloid protein: a study of the BrainNet Europe consortium. Acta Neuropathol 115(5):533-546. doi:10.1007/s00401-008-0358-2

2. Armstrong J, Boada M, Rey MJ, Vidal N, Ferrer I (2004) Familial Alzheimer disease associated with A713T mutation in APP. Neurosci Lett 370(2-3):241-243. doi:10.1016/j.neulet.2004. 08.026

3. Arnold SE, Hyman BT, Flory J, Damasio AR, Van Hoesen GW (1991) The topographical and neuroanatomical distribution of neurofibrillary tangles and neuritic plaques in the cerebral cortex of patients with Alzheimer's disease. Cereb Cortex 1(1):103-116

4. Aso E, Lomoio S, Lopez-Gonzalez I, Joda L, Carmona M, Fernandez-Yague N, Moreno J, Juves S, Pujol A, Pamplona R, Portero-Otin M, Martin V, Diaz M, Ferrer I (2011) Amyloid generation and dysfunctional immunoproteasome activation with disease progression in animal model of familial Alzheimer's disease. Brain Pathol. doi:10.1111/j.1750-3639.2011.00560.x

5. Balasa M, Vidal-Pineiro D, Llado A, Antonell A, Bosch B, Castellanos F, Bargallo N, Bartres-Faz D, Molinuevo JL, Sanchez-Valle R (2012) PSEN1 mutation carriers present lower cerebrospinal fluid amyloid- $\beta 42$ levels than sporadic early-onset Alzheimer's disease patients but no differences in neuronal injury biomarkers. J Alzheimers Dis 30(3):605-616. doi:10.3233/JAD2012-111949

6. Bateman RJ, Aisen PS, De Strooper B, Fox NC, Lemere CA, Ringman JM, Salloway S, Sperling RA, Windisch M, Xiong C (2011) Autosomal-dominant Alzheimer's disease: a review and proposal for the prevention of Alzheimer's disease. Alzheimers Res Ther 3(1): 1

7. Berezovska O, Lleo A, Herl LD, Frosch MP, Stern EA, Bacskai BJ, Hyman BT (2005) Familial Alzheimer's disease presenilin 1 mutations cause alterations in the conformation of presenilin and interactions with amyloid precursor protein. J Neurosci 25(11):3009-3017

8. Bittner T, Fuhrmann M, Burgold S, Jung CK, Volbracht C, Steiner H, Mitteregger G, Kretzschmar HA, Haass C, Herms J (2009) Gamma-secretase inhibition reduces spine density in vivo via an amyloid precursor protein-dependent pathway. J Neurosci 29(33):10405-10409. doi:10.1523/JNEUROSCI.2288-09.2009

9. Cai Y, Xiong K, Zhang XM, Cai H, Luo XG, Feng JC, Clough RW, Struble RG, Patrylo PR, Chu Y, Kordower JH, Yan XX (2010) $\beta$-Secretase- 1 elevation in aged monkey and Alzheimer's disease human cerebral cortex occurs around the vasculature in partnership with multisystem axon terminal pathogenesis and beta-amyloid accumulation. Eur J Neurosci 32(7):1223-1238. doi:10.1111/j.1460-9568.2010.07376.x

10. Cirrito JR, May PC, O’Dell MA, Taylor JW, Parsadanian M, Cramer JW, Audia JE, Nissen JS, Bales KR, Paul SM, DeMattos RB, Holtzman DM (2003) In vivo assessment of brain interstitial fluid with microdialysis reveals plaque-associated changes in amyloid-beta metabolism and half-life. J Neurosci 23(26):8844 8853 pii:23/26/8844

11. Citron M (2010) Alzheimer's disease: strategies for disease modification. Nat Rev Drug Discov 9(5):387-398. doi:10.1038/ $\operatorname{nrd} 2896$

12. Coma M, Guix FX, Ill-Raga G, Uribesalgo I, Alameda F, Valverde MA, Munoz FJ (2008) Oxidative stress triggers the amyloidogenic pathway in human vascular smooth muscle cells. Neurobiol Aging 29(7):969-980. doi:1016/j.neurobiolaging. 2007.01.009

13. Cras P, Kawai M, Lowery D, Gonzalez-DeWhitt P, Greenberg B, Perry G (1991) Senile plaque neurites in Alzheimer disease accumulate amyloid precursor protein. Proc Natl Acad Sci USA 88(17):7552-7556

14. Chau DM, Crump CJ, Villa JC, Scheinberg DA, Li YM (2012) Familial Alzheimer disease Presenilin-1 mutations alter the active site conformation of gamma-secretase. J Biol Chem. doi: 10.1074/jbc.M111.300483

15. Chavez-Gutierrez L, Bammens L, Benilova I, Vandersteen A, Benurwar M, Borgers M, Lismont S, Zhou L, Van Cleynenbreugel S, Esselmann H, Wiltfang J, Serneels L, Karran E, Gijsen H, Schymkowitz J, Rousseau F, Broersen K, De Strooper B (2012) The mechanism of gamma-secretase dysfunction in familial Alzheimer disease. EMBO J 31(10):2261-2274. doi:10.1038/ emboj.2012.79

16. Dominguez D, Tournoy J, Hartmann D, Huth T, Cryns $K$, Deforce S, Serneels L, Camacho IE, Marjaux E, Craessaerts K, Roebroek AJ, Schwake M, D'Hooge R, Bach P, Kalinke U, Moechars D, Alzheimer C, Reiss K, Saftig P, De Strooper B (2005) Phenotypic and biochemical analyses of BACE1- and BACE2-deficient mice. J Biol Chem 280(35):30797-30806. doi: 10.1074/jbc.M505249200

17. Fortea J, Llado A, Bosch B, Antonell A, Oliva R, Molinuevo JL, Sanchez-Valle R (2010) Cerebrospinal fluid biomarkers in Alzheimer's disease families with PSEN1 mutations. Neurodegener Dis 8(4):202-207

18. Fortea J, Llado A, Clarimon J, Lleo A, Oliva R, Peri J, Pintor L, Yague J, Blesa R, Molinuevo JL, Sanchez-Valle R (2011) PICOGEN: five years experience with a genetic counselling program for dementia. Neurologia 26(3):143-149

19. Fukumoto H, Cheung BS, Hyman BT, Irizarry MC (2002) Betasecretase protein and activity are increased in the neocortex in Alzheimer disease. Arch Neurol 59(9):1381-1389 pii:noc20210

20. Fukumoto H, Rosene DL, Moss MB, Raju S, Hyman BT, Irizarry MC (2004) Beta-secretase activity increases with aging in human, monkey, and mouse brain. Am J Pathol 164(2):719-725 pii:S0002-9440(10)63159-8

21. Ghiso J, Tagliavini F, Timmers WF, Frangione B (1989) Alzheimer's disease amyloid precursor protein is present in senile plaques and cerebrospinal fluid: immunohistochemical and biochemical characterization. Biochem Biophys Res Commun 163(1):430-437 pii:0006-291X(89)92154-2

22. Giliberto L, Borghi R, Piccini A, Mangerini R, Sorbi S, Cirmena G, Garuti A, Ghetti B, Tagliavini F, Mughal MR, Mattson MP, Zhu X, Wang X, Guglielmotto M, Tamagno E, Tabaton M (2009) Mutant presenilin 1 increases the expression and activity of BACE1. J Biol Chem 284(14):9027-9038. doi:10.1074/jbc.M8056 85200

23. Guardia-Laguarta C, Pera M, Clarimon J, Molinuevo JL, Sanchez-Valle R, Llado A, Coma M, Gomez-Isla T, Blesa R, Ferrer 
I, Lleo A (2010) Clinical, neuropathologic, and biochemical profile of the amyloid precursor protein $\mathrm{I716F}$ mutation. J Neuropathol Exp Neurol 69(1):53-59

24. Hardy J, Selkoe DJ (2002) The amyloid hypothesis of Alzheimer's disease: progress and problems on the road to therapeutics. Science 297(5580):353-356. doi:10.1126/science.1072994297/5580/353

25. Hata S, Fujishige S, Araki Y, Taniguchi M, Urakami K, Peskind E, Akatsu H, Araseki M, Yamamoto K, Martins RN, Maeda M, Nishimura M, Levey A, Chung KA, Montine T, Leverenz J, Fagan A, Goate A, Bateman R, Holtzman DM, Yamamoto T, Nakaya T, Gandy S, Suzuki T (2011) Alternative processing of gamma-secretase substrates in common forms of mild cognitive impairment and Alzheimer's disease: evidence for gammasecretase dysfunction. Ann Neurol 69(6):1026-1031

26. Hebert SS, Horre K, Nicolai L, Papadopoulou AS, Mandemakers W, Silahtaroglu AN, Kauppinen S, Delacourte A, De Strooper B (2008) Loss of microRNA cluster miR-29a/b-1 in sporadic Alzheimer's disease correlates with increased BACE1/beta-secretase expression. Proc Natl Acad Sci USA 105(17):6415-6420. doi: 10510.1073/pnas.0710263105

27. Holsinger RM, McLean CA, Beyreuther K, Masters CL, Evin G (2002) Increased expression of the amyloid precursor betasecretase in Alzheimer's disease. Ann Neurol 51(6):783-786. doi:10.1002/ana.10208

28. Ishii T, Kametani F, Haga S, Sato M (1989) The immunohistochemical demonstration of subsequences of the precursor of the amyloid A4 protein in senile plaques in Alzheimer's disease. Neuropathol Appl Neurobiol 15(2):135-147

29. Jiang Y, Mullaney KA, Peterhoff CM, Che S, Schmidt SD, Boyer-Boiteau A, Ginsberg SD, Cataldo AM, Mathews PM, Nixon RA (2010) Alzheimer's-related endosome dysfunction in Down syndrome is Abeta-independent but requires APP and is reversed by BACE-1 inhibition. Proc Natl Acad Sci USA 107(4):1630-1635. doi:10.1073/pnas.0908953107

30. Joachim C, Games D, Morris J, Ward P, Frenkel D, Selkoe D (1991) Antibodies to non-beta regions of the beta-amyloid precursor protein detect a subset of senile plaques. Am J Pathol 138(2):373-384

31. Kim HS, Kim EM, Lee JP, Park CH, Kim S, Seo JH, Chang KA, Yu E, Jeong SJ, Chong YH, Suh YH (2003) C-terminal fragments of amyloid precursor protein exert neurotoxicity by inducing glycogen synthase kinase-3beta expression. FASEB J 17(13):1951-1953. doi:10.1096/fj.03-0106fje03-0106fje

32. Lee JH, Yu WH, Kumar A, Lee S, Mohan PS, Peterhoff CM, Wolfe DM, Martinez-Vicente M, Massey AC, Sovak G, Uchiyama Y, Westaway D, Cuervo AM, Nixon RA (2010) Lysosomal proteolysis and autophagy require presenilin 1 and are disrupted by Alzheimer-related PS1 mutations. Cell 141(7):1146-1158. doi:10.1016/j.cell.2010.05.008

33. Lewczuk P, Kamrowski-Kruck H, Peters O, Heuser I, Jessen F, Popp J, Burger K, Hampel H, Frolich L, Wolf S, Prinz B, Jahn H, Luckhaus C, Perneczky R, Hull M, Schroder J, Kessler H, Pantel J, Gertz HJ, Klafki HW, Kolsch H, Reulbach U, Esselmann H, Maler JM, Bibl M, Kornhuber J, Wiltfang J (2010) Soluble amyloid precursor proteins in the cerebrospinal fluid as novel potential biomarkers of Alzheimer's disease: a multicenter study. Mol Psychiatry 15(2):138-145. doi:10.1038/mp.2008.84

34. Li R, Lindholm K, Yang LB, Yue X, Citron M, Yan R, Beach T, Sue L, Sabbagh M, Cai H, Wong P, Price D, Shen Y (2004) Amyloid beta peptide load is correlated with increased beta-secretase activity in sporadic Alzheimer's disease patients. Proc Natl Acad Sci USA 101(10):3632-3637. doi:10.1073/pnas.02056891010205689101

35. Llado A, Sanchez-Valle R, Rey MJ, Mercadal P, Almenar C, Lopez-Villegas D, Fortea J, Molinuevo JL (2010) New mutation in the PSEN1 (E120G) gene associated with early onset Alzheimer's disease. Neurologia 25(1):13-16
36. Lleo A, Blesa R, Queralt R, Ezquerra M, Molinuevo JL, PenaCasanova J, Rojo A, Oliva R (2002) Frequency of mutations in the presenilin and amyloid precursor protein genes in early-onset Alzheimer disease in Spain. Arch Neurol 59(11):1759-1763

37. Lleo A, Saura CA (2011) Gamma-secretase substrates and their implications for drug development in Alzheimer's disease. Curr Top Med Chem 11(12):1513-1527 pii:BSP/CTMC/E-Pub/000130-11-16

38. Mawuenyega KG, Sigurdson W, Ovod V, Munsell L, Kasten T, Morris JC, Yarasheski KE, Bateman RJ (2010) Decreased clearance of CNS beta-amyloid in Alzheimer's disease. Science 330(6012): 1774

39. McPhie DL, Lee RK, Eckman CB, Olstein DH, Durham SP, Yager D, Younkin SG, Wurtman RJ, Neve RL (1997) Neuronal expression of beta-amyloid precursor protein Alzheimer mutations causes intracellular accumulation of a C-terminal fragment containing both the amyloid beta and cytoplasmic domains. J Biol Chem 272(40):24743-24746

40. Mitani Y, Yarimizu J, Saita K, Uchino H, Akashiba H, Shitaka Y, Ni K, Matsuoka N (2012) Differential Effects between gammasecretase inhibitors and modulators on cognitive function in amyloid precursor protein-transgenic and nontransgenic mice. J Neurosci 32(6):2037-2050. doi:10.1523/JNEUROSCI.4264-11. 2012

41. Nixon RA, Yang DS (2011) Autophagy failure in Alzheimer's disease-locating the primary defect. Neurobiol Dis 43(1):38-45. doi:10.1016/j.nbd.2011.01.021

42. Oster-Granite ML, McPhie DL, Greenan J, Neve RL (1996) Agedependent neuronal and synaptic degeneration in mice transgenic for the $\mathrm{C}$ terminus of the amyloid precursor protein. J Neurosci 16(21):6732-6741

43. Perry G, Lipphardt S, Mulvihill P, Kancherla M, Mijares M, Gambetti P, Sharma S, Maggiora L, Cornette J, Lobl T et al (1988) Amyloid precursor protein in senile plaques of Alzheimer disease. Lancet 2(8613):746

44. Portelius E, Andreasson U, Ringman JM, Buerger K, Daborg J, Buchhave P, Hansson O, Harmsen A, Gustavsson MK, Hanse E, Galasko D, Hampel H, Blennow K, Zetterberg H (2010) Distinct cerebrospinal fluid amyloid beta peptide signatures in sporadic and PSEN1 A431E-associated familial Alzheimer's disease. Mol Neurodegener 5:2. doi:10.1186/1750-1326-5-2

45. Portelius E, Bogdanovic N, Gustavsson MK, Volkmann I, Brinkmalm G, Zetterberg H, Winblad B, Blennow K (2010) Mass spectrometric characterization of brain amyloid beta isoform signatures in familial and sporadic Alzheimer's disease. Acta Neuropathol 120(2):185-193. doi:10.1007/s00401-010-0690-1

46. Portelius E, Fortea J, Molinuevo JL, Gustavsson MK, Andreasson U, Sanchez-Valle R (2012) The amyloid-beta isoform pattern in cerebrospinal fluid in familial PSEN1 M139T- and L286P-associated Alzheimer's disease. Mol Med Report 5(4):1111-1115. doi:10.3892/mmr.2012.774

47. Preece P, Virley DJ, Costandi M, Coombes R, Moss SJ, Mudge AW, Jazin E, Cairns NJ (2003) Beta-secretase (BACE) and GSK3 mRNA levels in Alzheimer's disease. Brain Res Mol Brain Res 116(1-2):155-158 pii:S0169328X0300233X

48. Rosen C, Andreasson U, Mattsson N, Marcusson J, Minthon L, Andreasen N, Blennow K, Zetterberg H (2012) Cerebrospinal fluid profiles of amyloid beta-related biomarkers in alzheimer's disease. Neuromolecular Med 14(1):65-73. doi:10.1007/s12017012-8171-4

49. Russo C, Schettini G, Saido TC, Hulette C, Lippa C, Lannfelt L, Ghetti B, Gambetti P, Tabaton M, Teller JK (2000) Presenilin-1 mutations in Alzheimer's disease. Nature 405(6786):531-532. doi:10.1038/35014735

50. Sastre M, Dewachter I, Rossner S, Bogdanovic N, Rosen E, Borghgraef P, Evert BO, Dumitrescu-Ozimek L, Thal DR, 
Landreth G, Walter J, Klockgether T, van Leuven F, Heneka MT (2006) Nonsteroidal anti-inflammatory drugs repress beta-secretase gene promoter activity by the activation of PPARgamma. Proc Natl Acad Sci USA 103(2):443-448. doi:10.1073/pnas.0503839103

51. Saura CA, Chen G, Malkani S, Choi SY, Takahashi RH, Zhang D, Gouras GK, Kirkwood A, Morris RG, Shen J (2005) Conditional inactivation of presenilin 1 prevents amyloid accumulation and temporarily rescues contextual and spatial working memory impairments in amyloid precursor protein transgenic mice. J Neurosci 25(29):6755-6764. doi:10.1523/JNEUROSCI.1247-05.2005

52. Sepulveda-Falla D, Glatzel M, Lopera F (2012) Phenotypic profile of early-onset familial alzheimer's disease caused by presenilin-1 E280A mutation. J Alzheimers Dis 32(1):1-12. doi: 10.3233/JAD-2012-120907

53. Sepulveda-Falla D, Matschke J, Bernreuther C, Hagel C, Puig B, Villegas A, Garcia G, Zea J, Gomez-Mancilla B, Ferrer I, Lopera F, Glatzel M (2011) Deposition of hyperphosphorylated tau in cerebellum of PS1 E280A Alzheimer's disease. Brain Pathol 21(4):452-463. doi:10.1111/j.1750-3639.2010.00469.x

54. Shepherd C, McCann H, Halliday GM (2009) Variations in the neuropathology of familial Alzheimer's disease. Acta Neuropathol 118(1):37-52. doi:10.1007/s00401-009-0521-4

55. Tamagno E, Bardini P, Obbili A, Vitali A, Borghi R, Zaccheo D, Pronzato MA, Danni O, Smith MA, Perry G, Tabaton M (2002) Oxidative stress increases expression and activity of BACE in NT2 neurons. Neurobiol Dis 10(3):279-288 pii:S0969996102905152
56. Tian Y, Bustos V, Flajolet M, Greengard P (2011) A smallmolecule enhancer of autophagy decreases levels of $\mathrm{A} \beta$ and APPCTF via Atg5-dependent autophagy pathway. FASEB J 25(6):1934-1942. doi:10.1096/fj.10-175158

57. Yamada K, Cirrito JR, Stewart FR, Jiang H, Finn MB, Holmes BB, Binder LI, Mandelkow EM, Diamond MI, Lee VM, Holtzman DM (2011) In vivo microdialysis reveals age-dependent decrease of brain interstitial fluid tau levels in P301S human tau transgenic mice. J Neurosci 31(37):13110-13117. doi:10.1523/ JNEUROSCI.2569-11.2011

58. Yang LB, Lindholm K, Yan R, Citron M, Xia W, Yang XL, Beach T, Sue L, Wong P, Price D, Li R, Shen Y (2003) Elevated betasecretase expression and enzymatic activity detected in sporadic Alzheimer disease. Nat Med 9(1):3-4. doi:10.1038/nm01033nm0103-3

59. Zetterberg H, Andreasson U, Hansson O, Wu G, Sankaranarayanan S, Andersson ME, Buchhave P, Londos E, Umek RM, Minthon L, Simon AJ, Blennow K (2008) Elevated cerebrospinal fluid BACE1 activity in incipient Alzheimer disease. Arch Neurol 65(8):1102-1107. doi:10.1001/archneur.65.8.1102

60. Zhong Z, Ewers M, Teipel S, Burger K, Wallin A, Blennow K, He P, McAllister C, Hampel H, Shen Y (2007) Levels of betasecretase (BACE1) in cerebrospinal fluid as a predictor of risk in mild cognitive impairment. Arch Gen Psychiatry 64(6):718-726. doi:10.1001/archpsyc.64.6.718 